\section{Seed characterization and germination morpho-physiology of Simira gardneriana (Rubiaceae)}

\author{
Francival Cardoso Felix ${ }^{1}$ (D), Fabrícia Nascimento de Oliveira ${ }^{2}$ (D), Narjara \\ Walessa Nogueira de Freitas ${ }^{2}$ (D) Rômulo Magno Oliveira de Freitas ${ }^{3}$ (D), \\ Imtinen Ben Haj Jilani ${ }^{4}$ iD, Salvador Barros Torres ${ }^{2 *}$
}

\begin{abstract}
Simira gardneriana (Rubiaceae) is a newly discovered tree species endemic to the Caatinga. For this reason, studies aimed at propagation, seed and seedlings analysis are essential for morphology, identification, classification, and conservation. Our objective was to characterize the seeds, the morpho-physiology of germination and seedling establishment of S. gardneriana. Therefore, we performed physical, biometric, biochemical, and morphological characterization of the seeds, as well as an evaluation of the germination process and seedling establishment. Hydration of seeds was carried out by three methods (immersion in water, on a wire mesh, and between paper rolls) and at two temperatures $\left(25\right.$ and $30^{\circ} \mathrm{C}$ ). Morphological characterization of the seedlings was performed on paper substrate at $30^{\circ} \mathrm{C}$ for 28 days. Seeds of S. gardneriana are orthodox, amylo-lipid, have an endosperm and do not exhibit physical dormancy. Hydration and germination of the seeds can be achieved in a paper roll at $30^{\circ} \mathrm{C}$ with root protrusion on the sixth day, and complete seedling formation on the $28^{\text {th }}$ day after sowing. Seedlings of $S$. gardneriana are phanero-epigeal cotyledonous with photosynthetic cotyledons and have ability to regrow the root system. Characterization of $S$. gardneriana seeds, germination and seedlings contributes to its propagation and may help in subsequent taxonomic and phylogenetic studies in Rubiaceae.
\end{abstract}

Index terms: biometry, seed biochemistry, morphology, forest seeds, semiarid.

RESUMO: Simira gardneriana (Rubiaceae) é uma espécie arbórea recém-descoberta endêmica da Caatinga. Assim, estudos voltados à propagação, análise de sementes e plântulas são essenciais para a morfologia, identificação, classificação e conservação. Objetivou-se caracterizar as sementes, a morfofisiologia da germinação e o estabelecimento de plântulas de S. gardneriana. Para tanto, foi realizada a caracterização física, biométrica, bioquímica e morfológica das sementes, bem como avaliação do processo de germinação e estabelecimento das plântulas. A hidratação das sementes foi realizada por três métodos (imersão em água, tela metálica e rolos de papel) e duas temperaturas $\left(25\right.$ e $\left.30^{\circ} \mathrm{C}\right)$. A caracterização morfológica das plântulas foi realizada em substrato de papel a $30^{\circ} \mathrm{C}$ por 28 dias. As sementes de $S$. gardneriana são ortodoxas, amilo-lipídicas, possuem endosperma e não apresentam dormência física. A hidratação e a germinação das sementes podem ser realizadas em rolo de papel a $30^{\circ} \mathrm{C}$ com protrusão da raiz no sexto dia e formação completa de plântulas aos 28 dias após a semeadura. Plântulas de $S$. gardneriana são cotiledonares fanero-epigeais com cotilédones fotossintéticos e possuem capacidade de rebrota do sistema radicular. A caracterização de sementes, germinação e plântulas de $S$. gardneriana contribui para sua propagação e pode auxiliar em estudos taxonômicos e filogenéticos posteriores em Rubiaceae.

Termos para indexação: biometria, bioquímica de sementes, morfologia, sementes florestais, semiárido.
Journal of Seed Science, v.43, e202143025, 2021

http://dx.doi.org/10.1590/ 2317-1545v43250771

\author{
*Corresponding author \\ E-mail: sbtorres@ufersa.edu.br \\ Received: 4/6/2021. \\ Accepted: 7/27/2021.
}

${ }^{1}$ Universidade Federal do Paraná, 80210-170 - Curitiba, Paraná, Brasil.

${ }^{2}$ Universidade Federal Rural do Semi-Árido, 59625-900 - Mossoró, Rio Grande do Norte, Brasil.

${ }^{3}$ Instituto Federal de Educação, Ciência e Tecnologia, 59900-000 - Pau dos Ferros, Rio Grande do Norte, Brasil.

${ }^{4}$ Institut National Agronomique de Tunisie, 1082 - Tunis, Tunísia. 


\section{INTRODUCTION}

Simira gardneriana M.R.V. Barbosa \& Peixoto (Rubiaceae) is a newly discovered tree species endemic to the Caatinga ecosystem (Northeastern Brazil), occurring in Bahia, Ceará, Pernambuco and Piauí States (Barbosa, 2015). This ecoregion has temperatures of 27 and $29^{\circ} \mathrm{C}$, and records rainfall between 300 and $800 \mathrm{~mm}$ for three or five months (Moro et al., 2015). It belongs to the global biome Seasonally Dry Tropical Forests and Woodlands - SDTFW (Queiroz et al., 2017) which hosts the greatest diversity of species among the semiarid vegetation.

Commonly known as "pereiro-vermelho" or "pereiro-de-tinta", S. gardneriana is a deciduous tree, reaching 7 $\mathrm{m}$ in height. The wood and leaves are used for rural buildings, fences and as fodder (Barbosa and Peixoto, 2000), while the species is potentially suitable for urban afforestation and reforestation (Oliveira et al., 2017). Hence, the tremendous interest in conserving the species, especially since it grows in the Brazilian semiarid region, suffering from environmental devastation. Indeed, deforestation in the region is mainly due to logging, inadequate management of agriculture and extensive livestock activities, resulting in landscape fragmentation and a considerable loss of biodiversity (Coelho et al., 2014; Althoff et al., 2018).

The only available studies on $S$. gardneriana focus on the effects of substrate and abiotic stresses on seed germination (Oliveira et al., 2016; Oliveira et al., 2017; Oliveira et al., 2019). Nevertheless, there is no work dealing with the physical, biometric, morphological, and biochemical characterization of the seeds, nor the germination morpho-physiology and seedling establishment.

In fact, seed and seedling morphological characteristics are essential for better identification of vegetative structures, plant taxonomy, propagation, and easy recognition of the species at juvenile stage in the field (Oliveira et al., 2011; Felix et al., 2018), besides helping to interpret germination and vigor tests (Medeiros et al., 2020). In addition, it is important to correlate the species with its natural region of occurrence, in order to comprehend its propagation strategies under forest's environmental conditions (Cosmo et al., 2009; Pinto et al., 2012; Oliveira and Paoli, 2016).

Seed characterization provides information to help understand forest dynamics and differentiation between ecological groups of pioneer and non-pioneer species (Piña-Rodrigues et al., 2015). Moreover, it assists in determining the maximum seed lot size, the quantity of seeds needed for a germination test and other laboratory analyses (Brasil, 2013). These analyses are also necessary for the commercialization of seeds, in particular when the species is not included in the official recommended lists.

Furthermore, seed storage depends on data on desiccation tolerance and biochemical characterization of stored carbohydrate, lipid, and protein reserves (Bewley et al., 2013). Seeds draw energy from these biomolecules for germination and seedling establishment (Marcos-Filho, 2015). The relative proportions of these components and the filial storage tissue directly affect the storage, the germination, and the species establishment in forest environment.

Germination begins with seed imbibition which triggers metabolic processes and culminates in the elongation of the embryonic axis and the radicle protrusion (Carvalho and Nakagawa, 2012). For most species with non-dormant seeds, seed hydration follows a typical three-phase pattern (Bewley et al., 2013). This pattern is influenced by chemical composition and size of the seed, coat permeability, temperature conditions, contact with water and substrate composition during hydration (Marcos-Filho, 2015). A more detailed understanding of the germination process from seed hydration to seedling establishment may help considerably in the detection of dormancy (Baskin and Baskin, 2014), and the evaluation of germination and seedling period under laboratory conditions.

The Rubiaceae family has 39 tree species in the Caatinga, distributed in 29 botanical genera according to Flora do Brasil 2020 (Brasil, 2020). However, there are few studies related to the morphology of seeds and seedlings. Thus, our objective was to characterize the seeds and the morpho-physiology of germination and seedling establishment of $S$. gardneriana. Additionally, we tested the regrowth ability of seedling roots as an establishment strategy. 


\section{MATERIAL AND METHODS}

The seeds of $S$. gardneriana were manually collected from individuals at the beginning of the fruit dehiscence process, in the municipality of Afrânio ( $8^{\circ} 30^{\prime} 42^{\prime \prime} \mathrm{S}$ and $\left.41^{\circ} 00^{\prime} 36^{\prime \prime} \mathrm{W}\right)$, Pernambuco State, Brazil. They were then packed in paper bags (Kraft type) and stored in a cold room for three months $\left(10 \pm 2{ }^{\circ} \mathrm{C}, 50 \pm 2 \%\right.$ of relative humidity).

The physical characterization of the seeds was carried out by measuring the following parameters: thousand-seed weight (g) - calculated by weighing eight subsamples of 100 seeds (Brasil, 2009); number of seeds per kilogram calculated from the thousand-seed weight; seed moisture (\%) - determined by the oven drying method at $105 \pm 3{ }^{\circ} \mathrm{C}$ for $24 \mathrm{~h}$ (Brasil, 2009) with four replicates of $3 \mathrm{~g}$ of seeds; and biometry (mm) - length, width, and thickness of 400 seeds measured with a digital caliper $(0.05 \mathrm{~mm})$. Biometric data were analyzed using descriptive statistics (mean, standard deviation, and coefficient of variation).

The morphological characterization of seeds was performed on 100 seeds immersed in distilled water for $48 \mathrm{~h}$. Then, longitudinal sections were made through the seeds with a scalpel and examined under a stereomicroscope. Both external and internal characteristics were described. The former encompassed the shape, presence or absence of seed dispersal structures, integument color and border; the latter included the presence or absence of endosperm, type, shape, color and position of cotyledons and hypocotyl-radicle axis relative to the seed. Morphological characters of $S$. gardneriana seeds were described following the recommendations of Barroso et al. (1999).

The biochemical analysis was done with determination of reserve compounds stored in S. gardneriana seeds were evaluated in five 500-mg replicates to determine the contents of starch (Morris, 1948; McCready et al., 1950; Yemm and Willis, 1954), neutral lipids (Soxhlet, 1879), soluble proteins (Bradford, 1976; Alfenas et al., 1991), total soluble sugars (Morris, 1948; Yemm and Willis, 1954) and non-reducing sugars (Morris, 1948; Van-Handel, 1968). The results were expressed as percentage of dry weight of seeds.

The evaluation of the hydration process of seeds was assessed as a function of time by three methods (immersion in water, on a wire mesh, and between paper rolls) and at two temperatures ( 25 and $30^{\circ} \mathrm{C}$ ). These temperatures are those indicated for germination of S. gardneriana seeds (Oliveira et al., 2016; Oliveira et al., 2017; Oliveira et al., 2019).

The water immersion method consisted of soaking the seeds in plastic boxes $(11 \times 11 \times 3.5 \mathrm{~cm})$ with $100 \mathrm{~mL}$ of water changed every $12 \mathrm{~h}$. The wire mesh method was conducted with plastic boxes, containing inside a stainless-steel mesh where the seeds were distributed in a single layer with $100 \mathrm{~mL}$ of water at the bottom of the box. Regarding the paper roll method, the seeds were placed between three sheets of paper towels moistened with distilled water in an amount equal to 2.5 times the dry weight of the paper and packed in transparent plastic bags.

After putting of $S$. gardneriana seeds in their respective imbibition methods, they were placed in a germinator at 25 and $30^{\circ} \mathrm{C}$. Four replicates of 25 seeds for each interaction (three methods $x$ two temperatures) were initially weighed (zero time) on a precision balance $(0.001 \mathrm{~g})$, and in periods of $3,6,9,12,15,21,27,33,45,57,69$ and $81 \mathrm{~h}$, followed by weighing every $24 \mathrm{~h}$ until root protrusion $(\geq 2 \mathrm{~mm}$ ). The percentage of water absorbed at each imbibition period, was calculated in relation to the initial increase in seed weight for each method.

Morphological characterization of seedlings was performed on 200 seeds sown on a paper roll substrate moistened with distilled water and maintained in germinator at $30{ }^{\circ} \mathrm{C}$ for 28 days. The germination process was assessed daily and described from root protrusion $(\geq 2 \mathrm{~mm}$ ) until the appearance of the paracotyledons, observed under a stereomicroscope. Germination and seedling morphological characters of $S$. gardneriana were described following the terminology adopted by Barroso et al. (1999). Additionally, we evaluated the regrowth ability of the seedlings, by cutting the roots below the hypocotyl-root junction zone (collar) and keeping them under the same germination conditions for 28 days. 


\section{RESULTS AND DISCUSSION}

S. gardneriana seeds showed a moisture content of $12.3 \%$ at the time of natural dispersal, 14,500 seeds per kilogram (thousand-seed weight: $69.0 \mathrm{~g} ; 69 \mathrm{mg}$ per seed) and a germination reaching $90 \%$. Each seed has an average length of $12.72 \pm 1.58 \mathrm{~mm}$ (CV: $12.4 \%$ ), width of $8.25 \pm 1.0 \mathrm{~mm}$ (CV: $12.1 \%)$ and thickness of $1.12 \pm 0.22 \mathrm{~mm}$ (CV: 19.5\%). The results of the seed biometry showed a normally distributed data with a concentration of values and frequencies around the mean in each variable.

The low seed moisture associated with small seed size at dispersal indicates that $S$. gardneriana is a pioneer species and has orthodox seeds. These are dispersed with low moisture content in the Caatinga ecosystem (Oliveira et al., 2014; Correia et al., 2019; Nicolau et al., 2020). This class of seeds can be stored for a longer period of time under controlled conditions of temperature and humidity (Marcos-Filho, 2015). Therefore, studies on this topic need to be conducted to determine the ideal storage conditions for S. gardneriana.

According to Brasil (2013) and based on the results of the thousand-seed weight: the seed lot of S. gardneriana should have a maximum of $250 \mathrm{~kg}$; the average sample should contain 3,000 seeds; the purity analysis should be performed with 2,500 seeds; and the germination test should be performed with 400 seeds (four replicates of 100 seeds or eight replicates of fifty seeds). This information is important for marketing and evaluating seed germination when the species is not listed in official documents.

Seeds of $S$. gardneriana are winged (apical wing), lenticular-flat, oval-oblong to irregularly rounded in longitudinal section (Figure 1A), and elliptical in cross section. The coat is thin, caramel-brown, with dark brown margins, rounded and slightly acuminate at the base (Figure 1B). Internally, the seed has a white endosperm where the embryo is embedded (Figure 1C). The embryonic region (hypocotyl-radicular axis and cotyledons) is white in color (Figure 1D). The embryo is spatulate and occupies the basal part of the seed, with the cotyledonary leaves at the tip of the embryonic axis (Figures 1C and 1D). The hypocotyl-radicle axis is erect, and the cotyledons are foliaceous, symmetrical, and juxtaposed with well-marked ribs (Figure 1D).

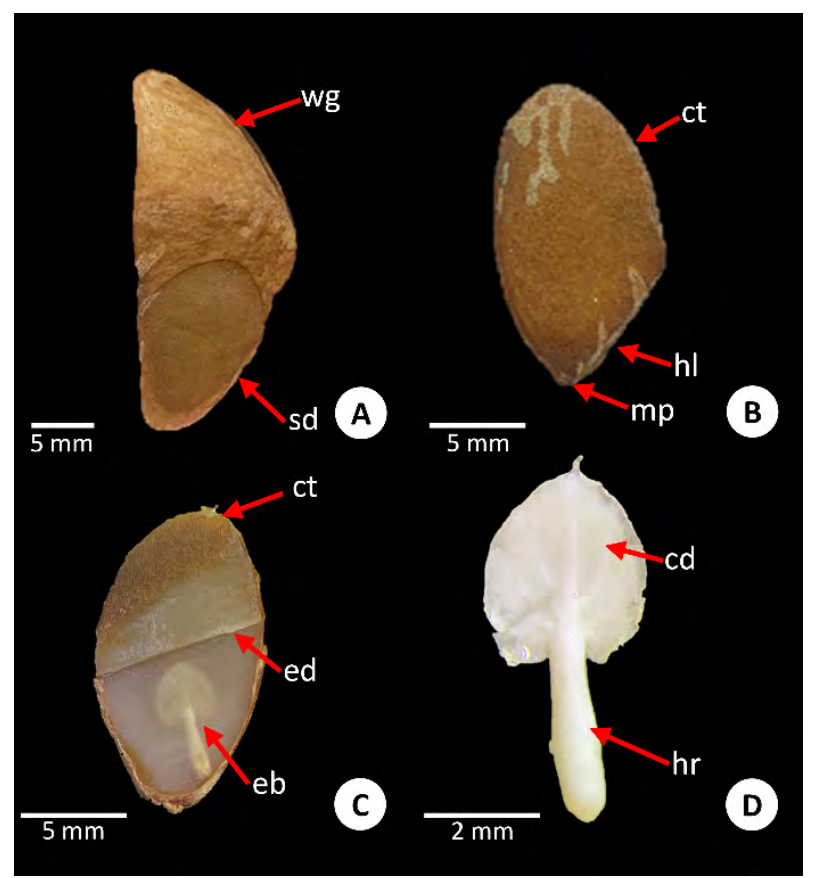

(A) Seed with wing; (B) Seed without wing; (C) Longitudinal section of the seed; and (D) Embryo. (cd: cotyledon; ct: coat; eb: embryo; ed: endosperm; hl: hilum; hr: hypocotyl-radicle axis; mp: micropyle; sd: seed; wg: wing).

Figure 1. External and internal morphology of Simira gardneriana seeds. 
Seeds of Rubiaceae family usually have a continuous, spatulate or foliaceous embryo, and the endosperm as the main reserve tissue (Barroso et al., 1999) as reported for Cordiera sessilis (Vell.) Kuntze (Matheus et al., 2008) and Genipa americana L. (Andrade et al., 2000). Only the genera Gleasonia, Henriquezia and Platycarpum have a more developed embryo and lack an endosperm (Barroso et al., 1999). Nevertheless, in Guettarda platypoda DC. there is no endosperm in the seeds (Lima et al., 2010), which justifies more comprehensive studies with this focus for each species.

The results of biochemical analysis revealed that $S$. gardneriana seeds contain $14.5 \%$ starch, $11.2 \%$ neutral lipids and $3.8 \%$ soluble proteins as the major reserve compounds, followed by $2.1 \%$ non-sugar reducing agents, and $2.1 \%$ total soluble sugars, and $66.3 \%$ other components (cellular structures of the embryo, endosperm, and coat). Therefore, the seeds of this species have higher amounts of starch (43\%) and lipids (33\%) between reserve compounds, especially in the endosperm which makes up most of the seed (Figure 1C). Structural carbohydrates, structural proteins and other molecules that make up cell structures were not evaluated in isolation, but may contribute to the development of the embryo during germination since all endosperm of the seed is consumed (Figures 3A-3D).

Reserves stored during seed maturation are used as an energy and carbon source for seed germination and embryo growth. Seedling establishment culminates with the transition from the heterotrophic to the autotrophic phase, at which time the first photosynthetic organs are fully developed (Bewley et al., 2013). Similarly, the reserves contained in the endosperm of $G$. americana are absorbed and used for leaf expansion and embryo growth during seedling establishment (Andrade et al., 2000).

S. gardneriana seeds did not show physical dormancy or restrictions on water entry. A three-phase water uptake pattern was observed for the assessed methods (Figures $2 \mathrm{~A}$ and $2 \mathrm{~B}$ ). The hydration method and incubation temperature affected the water uptake process of the seeds. The temperature of $30^{\circ} \mathrm{C}$ was favorable for seed hydration (Phases I and II) and radicle protrusion (Phase III) for the methods used.

Water uptake by seeds followed a three-phase pattern. Phase I hydration is characterized by a physical process of rapid water uptake at the onset of germination, regardless of whether the seeds are viable or not (Bewley et al., 2013). Nonetheless, only seeds that do not exhibit physical dormancy initiate this process (Baskin and Baskin, 2014). Phase II follows a stable increase in water and the beginning of reserve mobilization until radicle protrusion (Phase III) (Bewley et al., 2013). Assessment of these aspects is important for the detection of dormancy and the evaluation of germination time and seedling period under laboratory conditions.
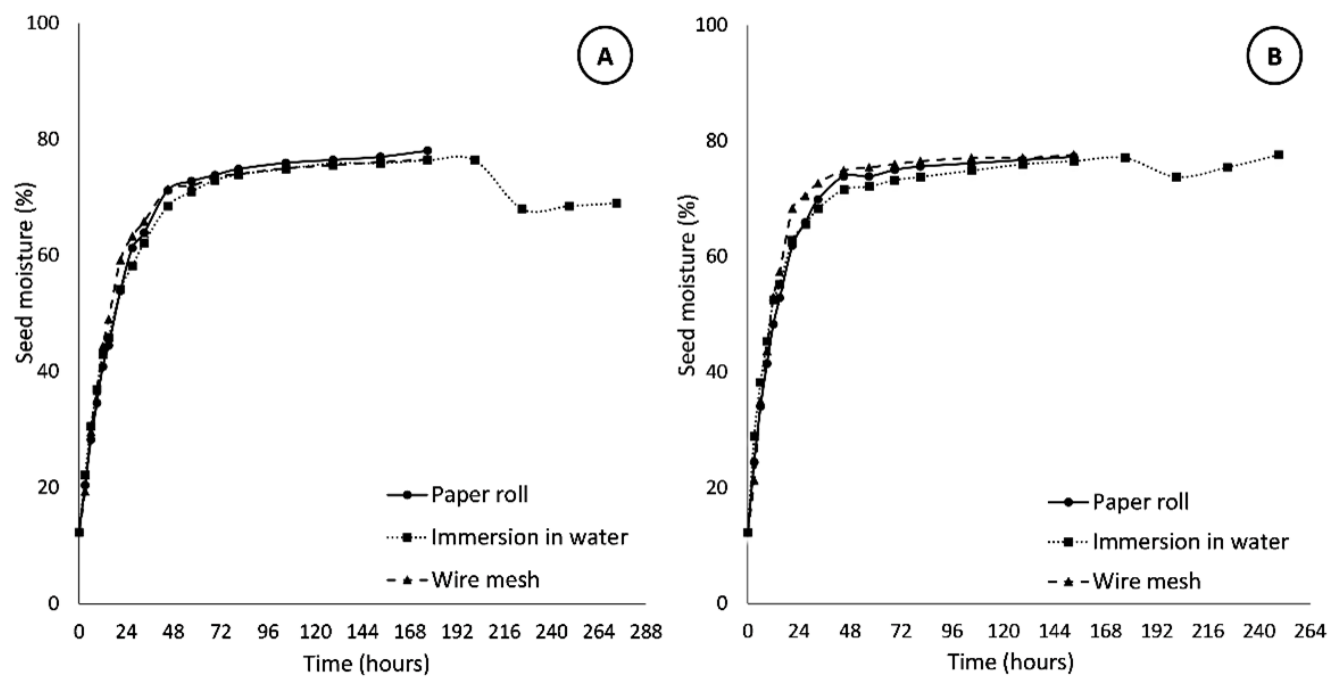

Figure 2. Hydration of Simira gardneriana seeds according to different imbibition methods (paper roll, immersion in water and on a wire mesh) at $25^{\circ} \mathrm{C}(\mathrm{A})$ and $30^{\circ} \mathrm{C}(\mathrm{B})$. 


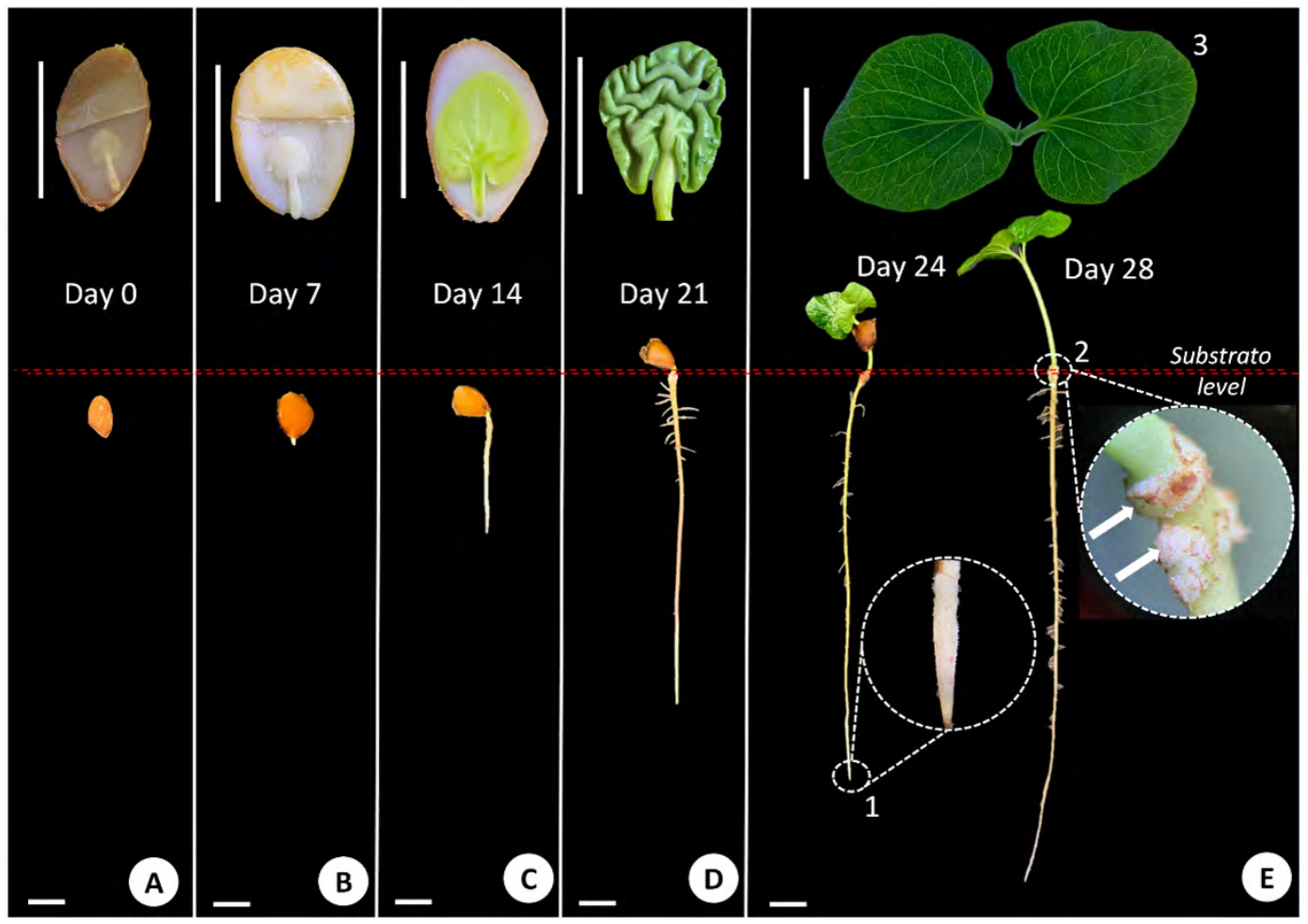

(A) Seed hydration; (B) Radicle protrusion; (C) Main root growth, cotyledon development and endosperm absorption; (D) Hypocotyl differentiation and complete endosperm absorption; (E) Emergence of cotyledonary leaves from the seed coat, and their expansion. 1: root growth zone; 2 : noticeable swelling formed at the collar; 3: cotyledonary leaves. Scale: $1 \mathrm{~cm}$.

Figure 3. Seed germination and seedling establishment of Simira gardneriana.

Phase I hydration of S. gardneriana seeds lasted on average $61 \mathrm{~h}\left(\sim 2.5\right.$ days) at $25^{\circ} \mathrm{C}$ and $53 \mathrm{~h}\left(\sim 2.2\right.$ days) at $30{ }^{\circ} \mathrm{C}$; while Phase II lasted on average $148 \mathrm{~h}\left(\sim 6.2\right.$ days) at $25^{\circ} \mathrm{C}$ and $132 \mathrm{~h}\left(\sim 5.5\right.$ days) at $30^{\circ} \mathrm{C}$, among the tested methods. Seeds placed to hydrate on a wire mesh and between paper rolls reached Phase III ( $177 \mathrm{~h}$ at $25^{\circ} \mathrm{C}, 153 \mathrm{~h}$ at $30^{\circ} \mathrm{C}$ ) faster than the immersion method $\left(273 \mathrm{~h}\right.$ at $25^{\circ} \mathrm{C}, 249 \mathrm{~h}$ at $\left.30^{\circ} \mathrm{C}\right)$.

Phase I typically lasts eight to $16 \mathrm{~h}$ for cultivars and can occur in up to two hours for some species (Carvalho and Nakagawa, 2012). Although increasing temperature has reduced the average hydration time in this phase. The slow hydration found in S. gardneriana is mainly associated with seed characteristics and varies among forest species. The residence time in Phase I was $12 \mathrm{~h}$ for Mimosa caesalpiniifolia Benth. (Fabaceae) and Pityrocarpa moniliformis (Benth.) Luckow \& R.W. Jobson (Fabaceae) (Nicolau et al., 2020), 24 h for Cenostigma pyramidale (Tul.) Gagnon \& G.P. Lewis (Fabaceae) (Dantas et al., 2008a) and $48 \mathrm{~h}$ for Schinopsis brasiliensis Engl. (Anacardiaceae) (Dantas et al., 2008b).

Hydration of seeds in a paper roll is more adequate at $30{ }^{\circ} \mathrm{C}$ because the seeds germinated faster $(153 \mathrm{~h}$ or $\sim$ six days) (Phase III) compared to the wire mesh ( seven days) and water immersion ( eleven days) methods. During Phase II hydration, the wire mesh method at both temperatures promoted fungal growth on the seed surface, whereas the water-immersed seeds showed high levels of deterioration with loss of biomass. Consequently, the latter two methods are not recommended for S. gardneriana.

The native Caatinga forest species reach Phase III in different periods, $36 \mathrm{~h}$ for $M$. caesalpiniifolia and $38 \mathrm{~h}$ for $P$. moniliformis (Nicolau et al., 2020), $54 \mathrm{~h}$ for C. pyramidale (Dantas et al., 2008a) and $152 \mathrm{~h}$ for S. brasiliensis (Dantas et al., 2008b). These differences are directly associated with seed characteristics for each species, regardless of botanical family. The development stage of the $S$. gardneriana embryo must be the determining factor for the longest germination time. 
Temperatures of 25 and $30^{\circ} \mathrm{C}$ are favorable for germination of S. gardneriana seeds, which have shown high seed viability ( 90\%) (Oliveira et al., 2016; Oliveira et al., 2017; Oliveira et al., 2019). Paper roll or sand substrates are indicated for seed germination of this species (Oliveira et al., 2016). Thus, confirming the need to aerate seeds during hydration to maintain viability.

Hydrating seeds directly in water can impair germination due to rapid water entry, promoting injuries and difficulty in aeration (Marcos-Filho, 2015), resulting in seed deterioration. Increased temperature and humidity accelerate seed metabolism and directly affect the process of imbibition, germination, and growth of fungi (Bewley et al., 2013), whose permanence can lead to seed deterioration and make germination unfeasible.

It was found that during water uptake and germination of $S$. gardneriana seeds, the embryo began to change its color to intense green and the endosperm was completely absorbed (Figures 3A-3D). Subsequently, the cotyledons completed their change from white to green, and the integument was ruptured for the complete emergence of the cotyledonary leaves (Figures 3D and 3E).

The seedlings of $S$. gardneriana are phanero-epigeal cotyledonous with photosynthetic cotyledons. The cotyledons rise above the substrate by elongation of the hypocotyl and its emergence from the seed coat. Germination began on the $6^{\text {th }}$ day after sowing, verified by the rupture of the integument and the root protrusion (Figure 3B). The radicle was cream-colored, extending to $25 \mathrm{~mm}$ and $50 \mathrm{~mm}$ on the $13^{\text {th }}$ and $15^{\text {th }}$ days after sowing (Figure 3C). The hypocotyl was green, and after the period of simultaneous growth of the main root and hypocotyl, the whitish secondary roots appeared (Figure 3D). The cotyledonary leaves detach from the seed coat on the $21^{\text {st }}$ and $24^{\text {th }}$ days after sowing and have a photosynthetic function (Figure 3E). After this period, the established seedling has a hypocotyl, photosynthetic cotyledons, an axial root, short, slender secondary roots (28 days) (Figure $3 \mathrm{E}$ ).

Slow germination was also found for other species of the Rubiaceae family that have phanero-epigeal seedlings with the cotyledonary leaves. Root protrusion of $G$. americana began on day eight after sowing and expansion of photosynthetic cotyledons occurred between days 17 and 34 (Andrade et al., 2000). G. platypoda seedling formation occurred between 25 and 29 days after the onset of germination (Lima et al., 2010). These authors emphasize that these species have a pioneer character of establishment in the forest.

Therefore, we can say that the small seed size of $S$. gardneriana associated with the wings allowed this seed to be dispersed and transported by wind. But makes it difficult to establish seedlings due to a lower energy reserve, as found for Aspidosperma pyrifolium Mart. \& Zucc. (Apocynaceae) (Correia et al., 2019) and Handroanthus impetiginosus (Mart. Ex DC.) Mattos (Bigoniaceae) (Felix et al., 2018). Wind dispersal and low seed water content are characteristics present in many Caatinga species (Oliveira et al., 2014; Santos et al., 2018; Correia et al., 2019).

It is noteworthy that at the hypocotyl-root junction zone, called collar, we observed a noticeable swelling of cells (Figures 3E, 4A). Some seedlings emitted secondary roots from this tissue, indicating the ability to regrow when the main root is lost. When the main root was cut (Figure 4B), the seedlings promote root regrowth after two weeks (Figure 4C), with full root establishment after 28 days (Figure 4D). The regrowth ability may then be a strategy to establish the species in a field situation or under environmental stresses.

The absence of physical dormancy and the photosynthetic cotyledons reinforce the pioneer feature of the species, characterized by an establishment soon after the first rains. Furthermore, the successful establishment of $S$. gardneriana seedlings depends on a wide location to obtain light after germination, if minimum moisture conditions are maintained, as the seedling takes about three/four weeks to fully develop. The ability to regrowth roots must be explored in future studies to better understand this strategy in S. gardneriana.

Interestingly, this study suggests a set of morpho-physiological and biochemical characters of $S$. gardneriana seeds and germination, as well as morphological features of its seedlings. This characterization not only contributes to the morphology, identification, conservation, propagation, and recognition of the species at juvenile stage in the field, once its natural regeneration is established; but it will greatly help in subsequent taxonomic and phylogenetic analyses of seed morphological characteristics in Rubiaceae. 

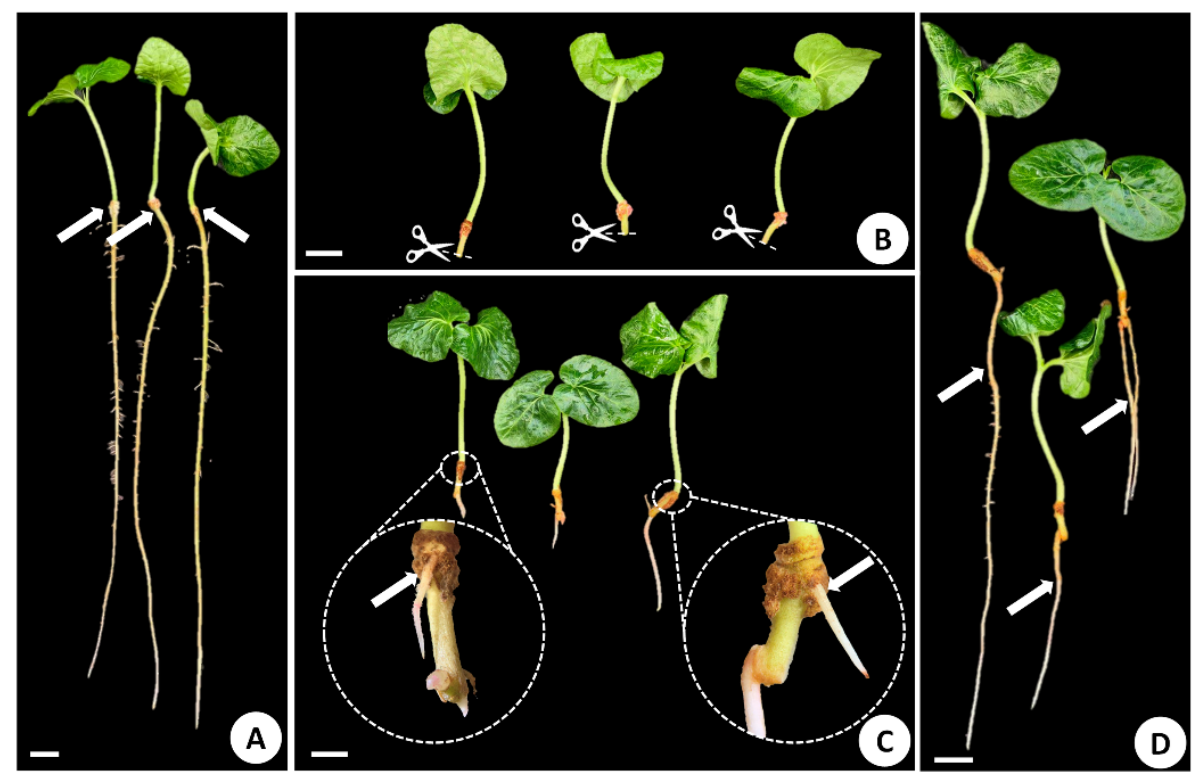

Scale: $1 \mathrm{~cm}$.

Figure 4. Complete seedlings of Simira gardneriana established on the $28^{\text {th }}$ day (A), root removal (B), root regrowth after fourteen days (C), and full root establishment after 28 days (D).

\section{CONCLUSIONS}

Seeds of S. gardneriana are tolerant to desiccation, have better germination capacity at $30{ }^{\circ} \mathrm{C}$ without impediments to the water entry. The characterization of seeds and seedlings contributes to the recognition of the species, and for evaluation period and adequate conditions for carrying out germination tests. The $S$. gardneriana seedlings establishment occurs with rapid photosynthetic and regrowth capacity. The regrowth in case of complete loss of the root system is a propagation strategy for the species.

\section{ACKNOWLEDGEMENTS}

The authors would like to thank the Centro de Referência para Recuperação de Áreas Degradadas (CRAD) of the Universidade Federal do Vale do São Francisco (UNIVASF), in particular Dr. José Alves de Siqueira-Filho, for providing the seeds to carry out this work.

In memory of Dr. Marcicleide Lima da Silva, professor at the Centro de Ciências Biológicas e da Saúde at the Universidade Federal Rural do Semi-Árido (UFERSA), victim of COVID-19 on April $10^{\text {th }}, 2021$, for the scientific contribution to the work.

\section{REFERENCES}

ALFENAS, A.C.; PETERS, I.; BRUNE, W.; PASSADOR, G.C. Eletroforese de proteínas e isoenzimas de fungos e essências florestais. Viçosa, MG: Universidade Federal de Viçosa, 1991. 242p.

ALTHOFF, T.D.; MENEZES, R.S.C.; PINTO, A.S.; PAREYN, F.G.C.; CARVALHO, A.L.; MARTINS, J.C.R.; CARVALHO, E.X.; SILVA, A.S.A.; DUTRA, E.D.; SAMPAIO, E.V.S.B. Adaptation of the century model to simulate $\mathrm{C}$ and $\mathrm{N}$ dynamics of Caatinga dry forest before and after deforestation. Agriculture, Ecosystems and Environment, v.254, p.26-34, 2018. https://doi.org/10.1016/j.agee.2017.11.016 
ANDRADE, A.C.S.; SOUZA, A.F.; RAMOS, F.N.; PEREIRA, T.S.; CRUZ, A.P.M. Seed germination of Genipa americana L. - Rubiaceae: temperature, substrate and post-seminal development. Pesquisa Agropecuária Brasileira, v.35, n.3, p.609-615, 2000. https://doi. org/10.1590/S0100-204X2000000300017

BARBOSA, M.R. Simira gardneriana in lista de espécies da flora do Brasil. Rio de Janeiro: Jardim Botânico do Rio de Janeiro, 2015. Available on: http://floradobrasil.jbrj.gov.br/jabot/floradobrasil/FB20858 Accessed on: 29 jan. 2021.

BARBOSA, M.R.V.; PEIXOTO, A.L. A new species of Simira (Rubiaceae, Rondeletieae) from Northeastern Brazil. Novon, v.10, n.2, p.110-112, 2000. https://doi.org/10.2307/3393006

BARROSO, G.M.; MORIM, M.P.; PEIXOTO, A.L.; ICHASO, C.L.F. Frutos e sementes: morfologia aplicada à sistemática de dicotiledôneas. Viçosa, MG: Universidade Federal de Viçosa, 1999. 443p.

BASKIN, C.C.; BASKIN, J.M. Seeds: ecology, biogeography, and evolution of dormancy and germination. $2^{\text {nd }}$ ed. San Diego, USA: Academic Press, 2014. 1586p.

BEWLEY, J.D.; BRADFORD, K.J.; HILHORST, H.W.M.; NONOGAKI, H. Seeds: physiology of development, germination and dormancy. $3^{\text {rd }}$ ed. New York, USA: Springer, 2013. 392p.

BRADFORD, M.M. A rapid and sensitive method for the quantitation of microgram quantities of protein utilizing the principle of protein-dye binding. Analitical Biochemistry, v.72, n.1, p.248-254, 1976. https://doi.org/10.1006/abio.1976.9999

BRASIL. Flora do Brasil. Programa REFLORA, 2020. Available on: http://floradobrasil.jbrj.gov.br/ Accessed on: 29 jan. 2021.

BRASIL. Ministério da Agricultura, Pecuária e Abastecimento. Regras para análise de sementes. Ministério da Agricultura, Pecuária e Abastecimento. Secretaria de Defesa Agropecuária. Brasília: MAPA/ACS, 2009. 399p. http:// https://www.gov.br/agricultura/ptbr/assuntos/insumos-agropecuarios/arquivos-publicacoes-insumos/2946_regras_analise_sementes.pdf

BRASIL. Ministério da Agricultura, Pecuária e Abastecimento. Instruções para análises de sementes de espécies florestais. Ministério da Agricultura, Pecuária e Abastecimento. Secretaria de Defesa Agropecuária. Brasília: MAPA/ACS, 2013. 98p. https://www.gov.br/ agricultura/pt-br/assuntos/laboratorios/arquivos-publicacoes-laboratorio/florestal_documento_pdf-ilovepdf-compressed.pdf

CARVALHO, N.M.; NAKAGAWA, J. Sementes: ciência, tecnologia e produção. $5^{\text {th }}$ ed. Jaboticabal, SP: Fundação de Apoio a Pesquisa, Ensino e Extensão, 2012. 590p.

COELHO, V.H.R.; MONTENEGRO, S.M.G.L.; ALMEIDA, C.N.; LIMA, E.R.V.; RIBEIRO-NETO, A.; MOURA, G.S.S. Dynamic of land use/ cover change processes in a Brazilian semiarid watershed. Revista Brasileira de Engenharia Agrícola e Ambiental, v.18, n.1, p.64-72, 2014. https://doi.org/10.1590/S1415-43662014000100009

CORREIA, L.A.S.; FELIX, F.C.; ARAÚJO, F.D.S.; FERRARI, C.D.S.; PACHECO, M.V. Morphometric descriptors and physiological seed quality for selecting Aspidosperma pyrifolium Mart. Matrix trees. Revista Caatinga, v.32, n.3, p.751-759, 2019. https://doi. org/10.1590/1983-21252019v32n319rc

COSMO, N.L.; GOGOSZ, A.M.; NOGUEIRA, A.C.; BONA, C.; KUNIYOSHI, Y.S. Fruit and seed morphology and morpho-anatomy of seedlings of Vitex megapotamica (Spreng.) Moldenke (Lamiaceae). Acta Botanica Brasilica, v.23, n.2, p.389-397, 2009. https://doi. org/10.1590/S0102-33062009000200010

DANTAS, B.F.; CORREIA, J.S.; MARINHO, L.G.; ARAGÃO, C.A. Biochemical changes during imbibition of Caesalpinia pyramidalis Tul. seeds. Journal of Seed Science, v.30, n.1, p.221-227, 2008a. https://doi.org/10.1590/S0101-31222008000100028

DANTAS, B.F.; SOARES, F.S.J.; LÚCIO, A.A.; ARAGÃO, C.A. Biochemical changes during imbibition of Schinopsis brasiliensis Engl. seeds. Journal of Seed Science, v.30, n.2, p.214-219, 2008b. https://doi.org/10.1590/S0101-31222008000200027

FELIX, F.C.; MEDEIROS, J.A.D.; PACHECO, M.V. Morphology of seeds and seedlings of Handroanthus impetiginosus (Mart. ex DC.) Mattos. Revista de Ciências Agrárias, v.41, n.4, p.1028-1035, 2018. https://doi.org/10.19084/RCA18126

LIMA, L.F.; LIMA, P.B.; ALMEIDA-JÚNIOR, E.B.; ZICKEL, C.S. Morphology of fruits, seeds and seedlings Guettarda platypoda DC. (Rubiaceae). Biota Neotropica, v.10, n.1, p.155-160, 2010. https://doi.org/10.1590/S1676-06032010000100015

MARCOS-FILHO, J. Fisiologia de sementes de plantas cultivadas. $2^{\text {nd }}$ ed. Londrina, PR: ABRATES, 2015. 660p. 
MATHEUS, M.T.; BACELAR, M.; OLIVEIRA, S.A.S. Morphological description of fruits and seeds of marmelinho-do-campo - Alibertia sessilis Schum. (Rubiaceae). Revista Caatinga, v.21, n.3, p.60-61, 2008. https://periodicos.ufersa.edu.br/index.php/caatinga/ article/view/696/389

MCCREADY, R.M.; GUGGOLZ, J.; SILVIERA, V.; OWENS, H.S. Determination of starch and amylose in vegetables: application to peas. Analytical Chemistry, v.22, n.9, p.1156-1158, 1950. https://doi.org/10.1021/ac60045a016

MEDEIROS, J.A.D.; NUNES, S.P.L.; FÉLIX, F.C.; FERRARI, C.S.; PACHECO, M.V.; TORRES, S.B. Vigor test of (strong) normal intact Amburana cearensis (Allemão) A.C. Smith seedlings. Journal of Seed Science, v.42, e202042011, 2020. https://doi.org/10.1590/2317$1545 v 42221611$

MORO, M.F.; SILVA, I.A.; ARAÚJO, F.S.; LUGHADHA, E.C.; MEAGHER, T.R.; MARTINS, F.R. The role of edaphic environment and climate in structuring phylogenetic patterns in seasonally dry tropical plant communities. PLoS One, v.10, n.3, e0119166, 2015. https://doi.org/10.1371/journal.pone.0119166

MORRIS, D.L. Quantitative determination of carbohydrates with dreywood's anthrone reagent. Science, v.107, n.2775, p.254-255, 1948. https://doi.org/10.1126/science.107.2775.254

NICOLAU, J.P.B.; SILVA, F.E.; FELIX, F.C.; TORRES, S.B.; PACHECO, M.V.; PEREIRA, M.D. Discontinuous hydration on the germination of Mimosa caesalpiniifolia and Pityrocarpa moniliformis seeds under water stress. Revista Caatinga, v.33, n.2, p.555-561, 2020. https://doi.org/10.1590/1983-21252020v33n228rc

OLIVEIRA, F.N.; CASTRO, T.H.S.; TORRES, S.B.; NOGUEIRA, N.W.; FREITAS, R.M.O. Germination and initial development of Simira gardneriana M.R. Barbosa \& Peixoto (Rubiaceae) seedlings under different temperatures and salinity levels. Semina: Ciências Agrárias, v.40, n.3, p.1023-1032, 2019. https://doi.org/10.5433/1679-0359.2019v40n3p1023

OLIVEIRA, F.N.; FRANÇA, F.D.; TORRES, S.B.; NOGUEIRA, N.W.; FREITAS, R.M.O. Temperature and substrate on the germination of seeds of Simira gardneriana M.R. Barbosa \& Peixoto. Revista Ciência Agronômica, v.47, n.4, p.658-666, 2016. https://doi. org/10.5935/1806-6690.20160079

OLIVEIRA, F.N.; OLIVEIRA, J.R.; TORRES, S.B.; FREITAS, R.M.O.; NOGUEIRA, N.W. Germination and initial development of Simira gardneriana seedling under water stress and at different temperatures. Revista Brasileira de Engenharia Agrícola e Ambiental, v.21, n,5, p.333-338, 2017. https://doi.org/10.1590/1807-1929/agriambi.v21n5p333-338

OLIVEIRA, G.M.; MATIAS, J.R.; RIBEIRO, R.C.; BARBOSA, L.G.; SILVA, J.E.S.; DANTAS, B.F. Germination of seeds of Caatinga native tree species at different temperatures. Scientia Plena, v.10, n.4, p.1-6, 2014.

OLIVEIRA, J.H.G.; PAOLI, A.A.S. Morphology and development of seedlings of Acalypha gracilis (Spreng.) Müll. Arg, Euphorbia cotinifolia L. and Jatropha gossypiifolia L. (Euphorbiaceae). Arnaldoa, v.23, n.2, p.443-460, 2016. https://doi.org/10.22497/ arnaldoa.232.23204

OLIVEIRA, M.T.R.; BERBERT, P.A.; PEREIRA, R.C.; VIEIRA, H.D.; CARLESSO, V.O. Biometry and physical-chemical characterization of Averrhoa carambola L. (Oxalidaceae) fruit and seed and seedling morphology. Journal of Seed Science, v.33, n.2, p.251-260, 2011. https://doi.org/10.1590/S0101-31222011000200007

PIÑA-RODRIGUES, F.C.M.; FIGLIOSA, M.B.; SILVA, A. Sementes florestais tropicais: da ecologia à produção. Londrina, PR: ABRATES, 2015. 477p.

PINTO, S.F.; MELO, M.G.G.; MENDES, A.M.S. Comparative morphology of propagules of Chrysophyllum amazonicum T. D. Penn. and Chrysophyllum prieurii A. D. Candolle. Journal of Seed Science, v.34, n.2, p.310-318, 2012. http://dx.doi.org/10.1590/S010131222012000200017

QUEIROZ, L.P.; CARDOSO, D.; FERNANDES, M.F.; MORO, M.F. Diversity and evolution of flowering plants of the Caatinga domain. In: SILVA, J.M.C.; LEAL, I.R.; TABARELLI, M. (ed.). New York, USA: Springer, 2017. p.23-63.

SANTOS, J.C.C.; SILVA, D.M.R.; COSTA, R.N.; SILVA, C.H.; SANTOS, W.S.; MOURA, F.B.P.; SILVA, J.V. Biometric and morphological aspects of the fruits and seeds of Schinopsis brasiliensis. Nativa, v.6, n.3, p.219-224, 2018. https://doi.org/10.31413/nativa.v6i3.4709

SOXHLET, F. Die gewichtsanalytische bestimmung des milchfettes. Dingler's Polytechnisches Journal, v.232, p.461-465, 1879. http:// dingler.culture.hu-berlin.de/article/pj232/ar232136 
VAN-HANDEL, E. Direct microdetermination of sucrose. Analytical Biochemistry, v.22, n.2, p.280-283, 1968. https://doi. org/10.1016/0003-2697(68)90317-5

YEMM, E.W.; WILLIS, A.J. The estimation of carbohydrates in plant extracts by anthrone. Biochemical Journal, v.57, n.3, p.508-514, 1954. https://doi.org/10.1042/bj0570508 